\title{
Evaluation of antitumor activities of different epigeic earthworms
}

\author{
Soumya R. Patil, Pulikeshi M. Biradar* \\ Department of Zoology, Karnatak University, Dharwad, India
}

\begin{tabular}{l}
\hline ARTICLE INFO \\
\hline Article history: \\
Received on: December 21, 2019 \\
Accepted on: March 20, 2020 \\
Available online: July 30, 2020 \\
\hline
\end{tabular}

Key words:

Antitumor activity, epigeic

earthworms (Eudrilus eugeniae,

Eisenia fetida, Perionyx

excavatus), MCF-7 cells and

MTT assay

\begin{abstract}
Earthworms have a long association with the medicinal property as the biomolecules/compounds produced by the earthworms are of pharmacological importance with high potential in the eradication of various diseases with very low cost. Researchers have proved that earthworms are immune to malignant diseases such as different kinds of cancers. Hence, the present study was undertaken to evaluate the antitumor activities of different epigeic earthworms, such as Eudrilus eugeniae, Eisenia fetida, and Perionyx excavatus. The cytotoxicity assay was tested through 3-(4,5-Dimethylthiazol-2-Y1)-2,5-Diphenyltetrazolium Bromide (MTT) assay on Michigan Cancer Foundation-7 (MCF-7) cells by exposing them at various concentrations $(200,400,600,800$, and 1,000 $\mu \mathrm{g} / \mathrm{ml})$ of different epigeic earthworm powders and standard antitumor chemotherapy drug Cisplatin $(15 \mu \mathrm{g} / \mathrm{ml})$. The percent growth inhibition/percent viability of MCF-7 cells varies with different concentrations of earthworm powder. The $\mathrm{IC}_{50}$ value was more prominent with $E$. fetida $(113.97 \mu \mathrm{g} / \mathrm{ml})$, followed by E. eugeniae $(825.67 \mu \mathrm{g} /$ $\mathrm{ml})$ and $P$. excavatus $(1,617.31 \mu \mathrm{g} / \mathrm{ml})$. Based on the above results, it can be concluded that the tissues of the earthworm, E. fetida, seems to be a very good anticancer agent against MCF-7 cells as compared to other two earthworm species. Therefore, such studies could be useful in the future for the development of novel therapeutic agents against different types of cancers, further molecular level experimental studies are required to ascertain the pathways and genes responsible for the anticancer effect, and thereby, we can exploit the beneficial aspects of various earthworm species in drug delivery research and also in pharmaceutical applications.
\end{abstract}

\section{INTRODUCTION}

The main problem encountered in combating cancer is the uncontrolled proliferation/division of cancer cells and metastasis. It is influenced by either the inherent properties of tumor cells, systemic nature, or local environmental factors [1]. About 90.50 million people had already different types of cancers, and about 14.10 million new cases occur every year, which leads to a death count of 8.8 million people [2]. The most common type of cancers in male is lung, prostate, colorectal, and stomach cancers, whereas in females are breast, colorectal, lung, and cervical cancers [3-5]. The financial costs to treat all these cancers were estimated at about $\$ 1.16$ million USD/ year as of 2010 [6].

Over the past few decades, researchers have explored alternative therapies and remedies to prevent cancer progression but have reached very low success rates. Chemotherapy is the only option but plays like a double-edged sword. Apart from killing cancer

*Corresponding Author

Pulikeshi M. Biradar, Department of Zoology, Karnatak University, Dharwad, India.E-mail: pulikeshi123@gmail.com cells, it also kills certain other adult cells that divide rapidly in the body, for example, the cells of gastro-intestinal linings, bone marrow, and hair follicle cells, thereby causing a significant influence on other parts of the body [7].

Natural products have been regarded as important resources that could produce potential chemotherapeutic agents. Since 1960, over $50 \%$ of anticancer drugs approved by the Food and Drug Administration, USA, were originated from natural resources [8]. Most of the animal resources have been used in medicine for the treatment of many diseases. Among invertebrates, earthworms have been wonderful organisms by virtue of their behavior as a source of food as it naturally contains a good amount of biological molecules such as proteins, minerals, and fatty acids [9-11]. Very few people are aware of earthworm association with medicine despite the availability of literature right from the 14th century. Burma and China claim that earthworms are resources of various bioactive compounds, which are found to be new potentials in the production of new life-saving drugs for cardiovascular and inflammation diseases including cancer $[12,13]$. The literature revealed that earthworms can synthesize a variety of immune protective biological molecules that exhibit different biological 
activities, such as anticoagulative, antimicrobial, fibrolytic, and antipyretic. They possess an innate immune system to carry out some functions associated with adaptive immunity [14,15] and are exploited for the treatment of a variety of diseases such as antimicrobial and anticancer activities [16].

The concept of using natural products produced out of earthworms such as coelomic fluid (CF) and other important proteins can inhibit the proliferation of cancer cells [17]. With the development of biochemical techniques, the research on the usages of earthworms in pharmaceuticals has been explored and witnessed that earthworms found to have antitumor effects [18]. The antiproliferative potentials of CF of different earthworm species have been evaluated by many workers [19-21], but little work was noticed with respect to antiproliferative/antitumor activities by using different epigeic earthworm species extracts. Therefore, the present study was undertaken to evaluate the antiproliferative activity/efficiency of different epigeic earthworms on MCF-7 cells through 3-(4,5-Dimethylthiazol-2-Y1)-2,5-Diphenyltetrazolium Bromide (MTT) assay.

\section{MATERIALS AND METHODS}

\subsection{Collection of Earthworms}

Adult epigeic earthworms, such as Eudrilus eugeniae (EE), Eisenia fetida (EF), and Perionyx excavates (PE) were obtained from a stock culture maintained at the Department of Zoology, Karnatak University, Dharwad (Karnataka), India.

\subsection{Preparation of Earthworm Powder}

The adult earthworms of all three species were initially washed in tap water and fed with a wet blotting paper for 20-24 hours so as to clear up the gut contents. The gut cleaned worms were again washed in distilled water, then were kept in tightly closed petriplates, and exposed to sunlight for 2-3 days to get brown colored earthworm powder containing its mucus, CF, and other oozed out materials of earthworms.

\subsection{In vitro Cytotoxicity by MTT Assay}

Several assays have been developed for measuring the cell viability and cytotoxicity tests. Cytotoxicity studies broadly involve the metabolic modification of cells including death due to toxic effects of the compounds. An in vitro cytotoxicity test eliminates the use of animals, and it is cost effective. Based on the literature review, the MTT assay is widely accepted as a reliable method to examine the proliferation of cells.

An in vitro cytotoxicity assay of different epigeic earthworm (E. eugeniae, E. fetida, and P. excavatus) powders was estimated by using a procedure described by Mosmann [22]. The MCF-7 cells (Michigan Cancer Foundation-Breast cancer cell lines) were grown in Dulbecco's Minimum Essential Medium (DMEM) at $37^{\circ} \mathrm{C}$ in $5 \% \mathrm{CO}_{2}$ incubator; the cells were trypsinized and aspirated into 15 $\mathrm{ml}$ centrifuge tube. The cell pellet was obtained by centrifugation at $300 \times \mathrm{g}$; the cell count was adjusted with DMEM so that $200 \mu \mathrm{l}$ of suspension contains about 10,000 cells.

To each well of 96-well microtiter plate, $200 \mu \mathrm{l}$ of cell suspension was added, and the plate was incubated at $37^{\circ} \mathrm{C}$ in $5 \% \mathrm{CO}_{2}$ incubator for 24 hours. After 24 hours, the spent medium was aspirated. About $200 \mu \mathrm{l}$ of different sample test concentrations $(200,400,600,800$, and $1,000 \mu \mathrm{g} / \mathrm{ml}$ from stock) and test chemotherapy drug Cisplatin $(15 \mu \mathrm{g} / \mathrm{ml})$ were added to the respective wells in duplicates. The plates were incubated for 24 hours again, then the plates were removed, and the drug containing media were aspirated. About $200 \mu \mathrm{l}$ of medium containing $10 \%$ MTT reagent was added to each well to get a final concentration of $0.5 \mathrm{mg} / \mathrm{ml}$, and then the plate was incubated for 3 hours. The culture medium was removed completely without disturbing the formed crystals, and then 100 $\mu 1$ of solution, dimethyl sulfoxide (DMSO) was added. The plate was gently shaken in a gyratory shaker to solubilize the colored formazan product. After 30 minutes of incubation, the optical density (OD) was measured by using a microplate reader at a wavelength between $570 \mathrm{~nm}$ and $630 \mathrm{~nm}$.

The percent growth inhibition or percent viability of different sample test concentrations and standard chemotherapy drug Cisplatin $(15 \mu \mathrm{g} / \mathrm{ml})$ was calculated. The concentration of test drug needed to inhibit the cell growth by $50 \%\left(\mathrm{IC}_{50}\right.$ value) was generated from the dose response curve for the cell line.

\section{RESULTS}

The cytotoxicity assay was tested on MCF-7 cells by exposing them at various test concentrations $(200,400,600,800$, and 1,000 $\mu \mathrm{g} / \mathrm{ml}$ ) of different epigeic earthworm powders and standard antitumor chemotherapy drug Cisplatin $(15 \mu \mathrm{g} / \mathrm{ml})$.

The results of the in vitro cytotoxicity studies are shown in Table 1, Figures $1-3$, and Plates $1-3$. The percent viability and $\mathrm{IC}_{50}$ value of MCF-7 cells vary with different test concentrations of all three epigeic earthworm species (Plates $1-3$ ). The $\mathrm{IC}_{50}$ value means a particular concentration of test sample required to reduce half of the cells from the total population. In case of E. eugeniae and $P$. excavatus, the percent viability decreases with increasing test concentrations, i.e., the percent viability is inversely proportional to the test concentrations. The $\mathrm{IC}_{50}$ value was more $(1,617.39 \mu \mathrm{g} / \mathrm{m})$ in $P$. excavatus and outside the test concentrations $(1,000 \mu \mathrm{g} / \mathrm{m})$ followed by E. eugeniae $(825.67 \mu \mathrm{g} / \mathrm{ml})$. In case of E. fetida, the percent viability is directly proportional to the test concentrations that means it increases with the increasing test concentrations having a minimum $\mathrm{IC}_{50}$ value of $113.97 \mu \mathrm{g} / \mathrm{ml}$ (Table 1). The tissue of E. fetida seems to be a very good anticancer agent against MCF7 cells as compared with other two earthworm species, E. eugeniae and $P$. excavatus. The $\mathrm{IC}_{50}$ value of $E$. fetida was more $(113.97 \mu \mathrm{g} /$ $\mathrm{ml}$ ) than that of a positive control standard chemotherapy drug Cisplatin (Table 1 and Figs. 1-3).

In this study, the earthworm powders of E. eugeniae, E. fetida, and $P$. excavatus showed a dose-dependent inhibition of growth or percent viability on MCF-7 cells (Table 1 and Figs. 1-3). The result of the current study demonstrates that the earthworm extracts (E. fetida) have potential bioactive compounds involved in strong antitumor activity. The cytotoxicity effect of these earthworm extracts may be related to the components present in the tissues of earthworms such as proteins and peptides. An increase or decrease in cell number resulting in a concomitant change in the formation of formazan indicates the degree of cytotoxicity (Plates 1-3). 
Table 1: Results of MTT assay with respect to percent viability and $\mathrm{IC}_{50}$ values of untreated, standard drug Cisplatin (Control) and various test concentrations of different epigeic earthworms.

\begin{tabular}{|c|c|c|c|c|c|}
\hline SI. No. & Test samples and Earthworm species & $\begin{array}{c}\text { Concentrations of test samples } \\
\qquad(\mu \mathrm{g} / \mathrm{ml})\end{array}$ & OD at $570-630 \mathrm{~nm}$ & Percent viability (\%) & IC $_{50}$ values \\
\hline 1 & Untreated & 0.0 & 1.12 & 100 & \multirow{9}{*}{$825.67 \mu \mathrm{g} / \mathrm{ml}$} \\
\hline \multirow[t]{3}{*}{2} & $\begin{array}{l}\text { Standard drug Cisplatin } \\
\text { (control) }\end{array}$ & 15 & 0.05 & 4.59 & \\
\hline & & 200 & 1.14 & 102.41 & \\
\hline & & 400 & 0.83 & 74.46 & \\
\hline \multirow[t]{5}{*}{3} & E. eugeniae & 600 & 0.73 & 65.58 & \\
\hline & & 800 & 0.53 & 47.94 & \\
\hline & & 1000 & 0.45 & 40.75 & \\
\hline & & 200 & 0.74 & 66.11 & \\
\hline & & 400 & 1.07 & 95.84 & \\
\hline \multirow[t]{5}{*}{4} & E. fetida & 600 & 1.29 & 115.66 & \multirow[t]{5}{*}{$113.97 \mu \mathrm{g} / \mathrm{ml}$} \\
\hline & & 800 & 1.32 & 118.25 & \\
\hline & & 1000 & 1.49 & 133.08 & \\
\hline & & 200 & 1.33 & 119.33 & \\
\hline & & 400 & 1.16 & 103.61 & \\
\hline \multirow[t]{3}{*}{5} & P. excavatus & 600 & 1.03 & 92.05 & \multirow{2}{*}{$1,617.39 \mu \mathrm{g} / \mathrm{ml}^{\mathrm{a}}$} \\
\hline & & 800 & 0.98 & 87.81 & \\
\hline & & 1,000 & 0.91 & 81.25 & $>1,000 \mu \mathrm{g} / \mathrm{ml}$ \\
\hline
\end{tabular}

$\mathrm{IC}_{50}=$ Inhibition concentration to kill $50 \%$ of organisms; $\mathrm{OD}=$ Optical density;

${ }^{*} \mathrm{IC}_{50}$ values outside the test concentrations range.
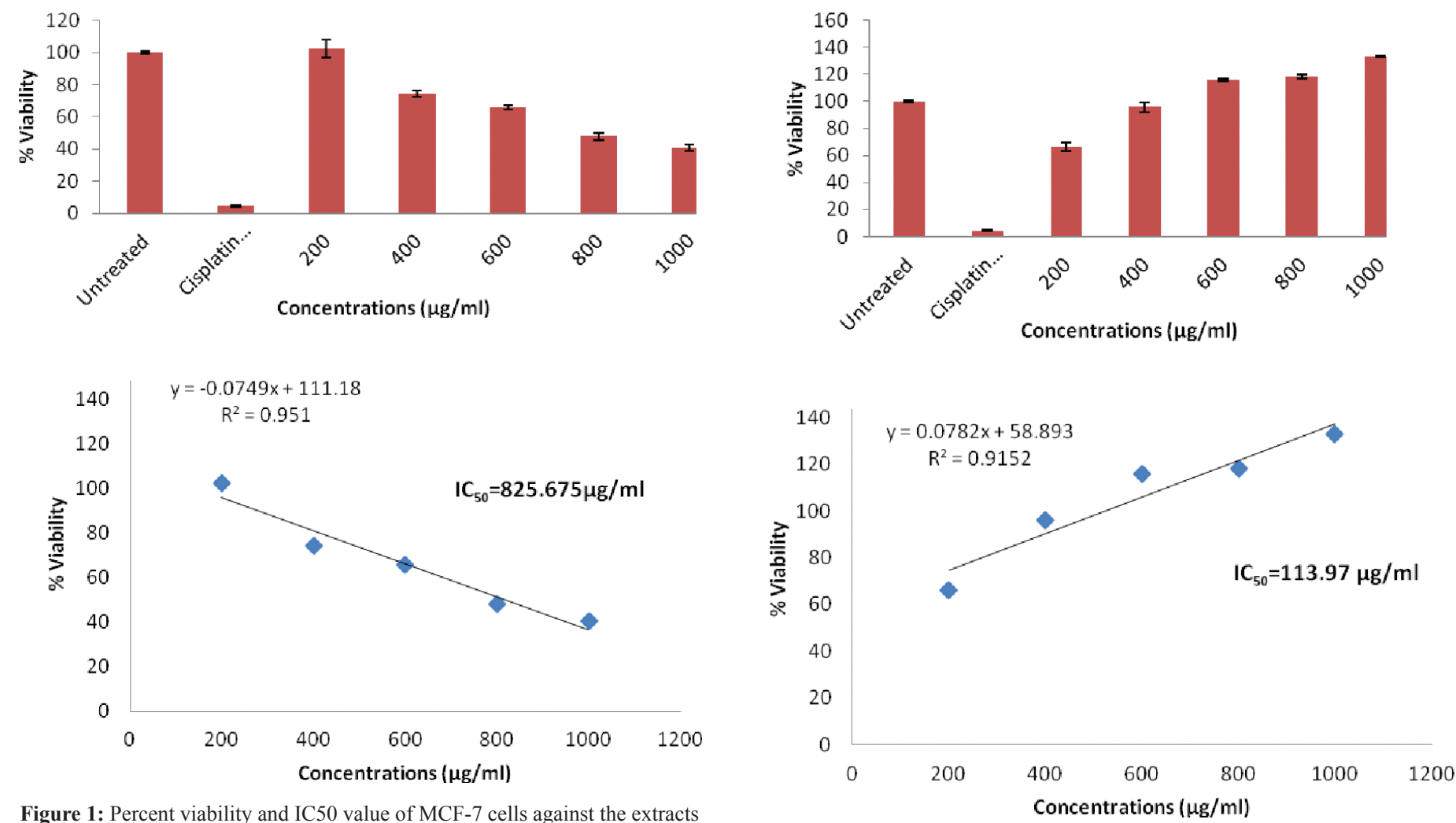

Figure 1: Percent viability and IC50 value of MCF-7 cells against the extracts of earthworm, E. eugeniae.

Figure 2: Percent viability and $\mathrm{IC}_{50}$ value of MCF-7 cells against the extracts of earthworm, E. fetida. 


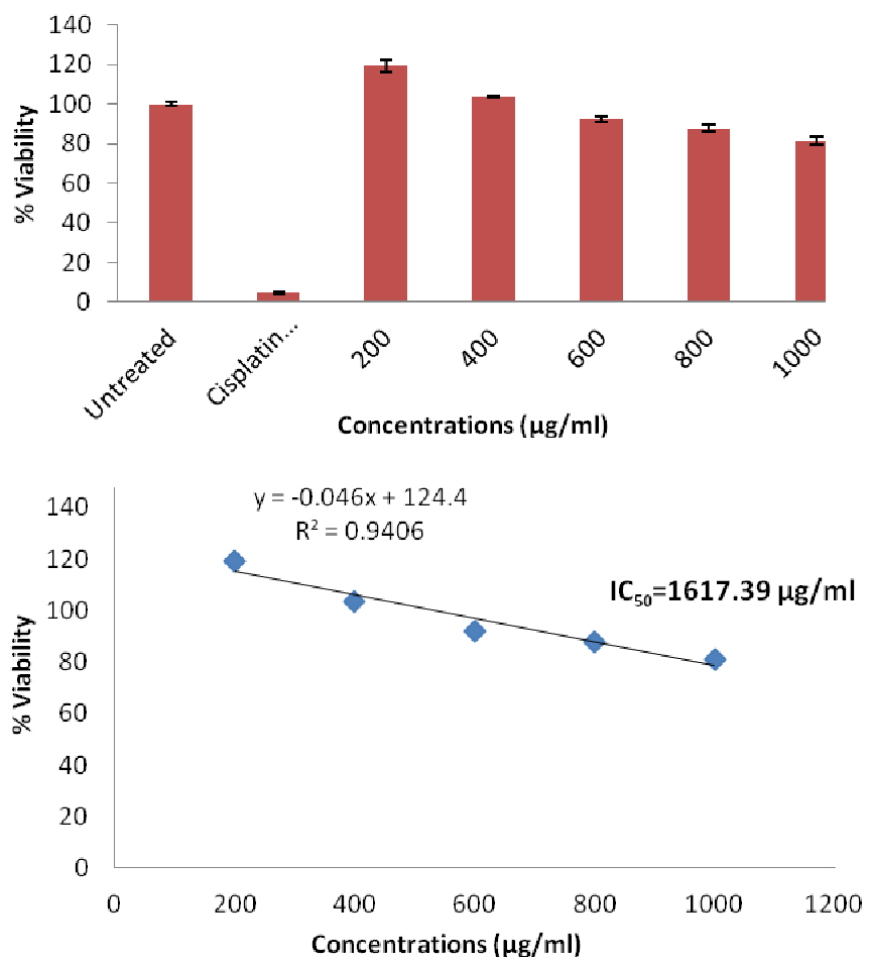

Figure 3: Percent viability and $\mathrm{IC}_{50}$ value of MCF-7 cells against the extracts of earthworm, P. excavatus.

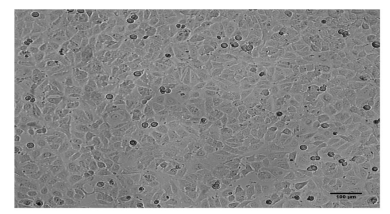

Untreated

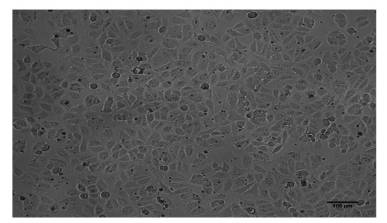

$\mathrm{EE}-200 \mu \mathrm{g} / \mathrm{ml}$

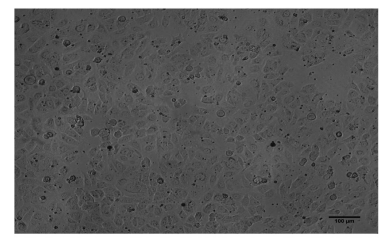

$\mathrm{EE}-600 \mu \mathrm{g} / \mathrm{ml}$

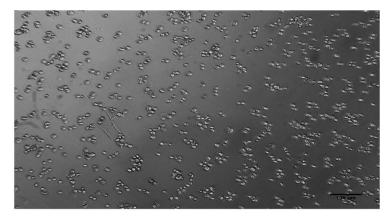

Cisplatin

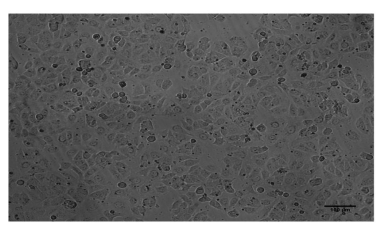

$\mathrm{EE}-400 \mu \mathrm{g} / \mathrm{ml}$

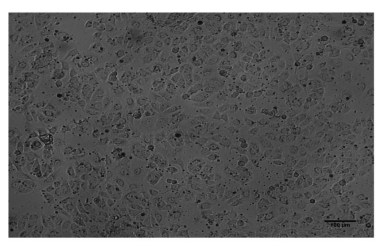

$\mathrm{EE}-800 \mu \mathrm{g} / \mathrm{ml}$

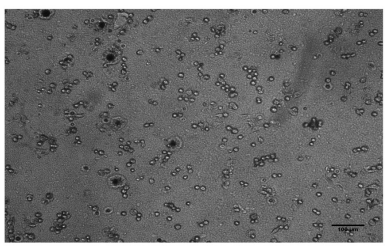

$\mathrm{EE}-1000 \mu \mathrm{g} / \mathrm{ml}$

Plate 1: Images of antitumor activities (\% viability of MCF-7 Cells) of untreated, standard drug Cisplatin $(15 \mu \mathrm{g} / \mathrm{ml})$ and various test concentrations $(200,400,600,800$ and $1,000 \mu \mathrm{g} / \mathrm{ml})$ of E. eugeniae (EE).

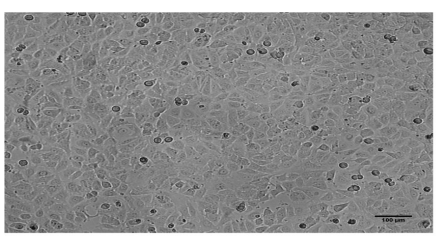

Untreated

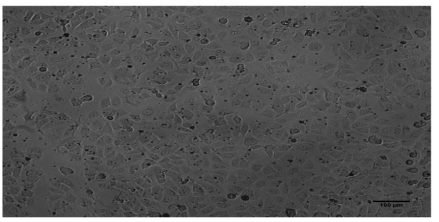

$\mathrm{EF}-200 \mu \mathrm{g} / \mathrm{ml}$

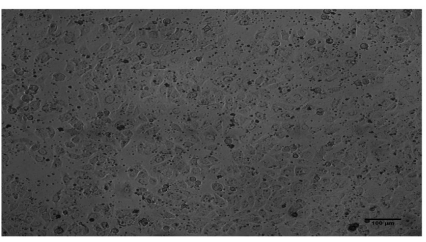

$\mathrm{EF}-600 \mu \mathrm{g} / \mathrm{ml}$

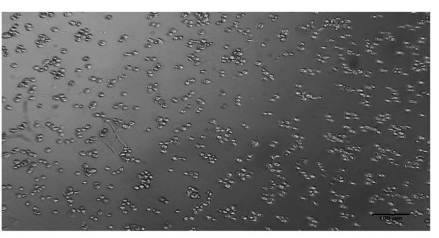

Cisplatin

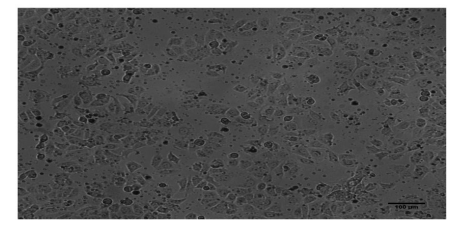

$\mathrm{EF}-400 \mu \mathrm{g} / \mathrm{ml}$

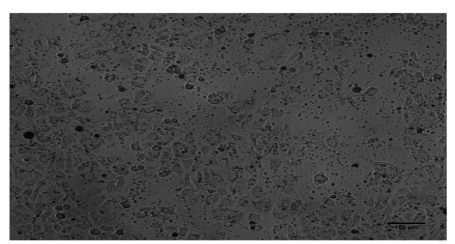

$\mathrm{EF}-800 \mu \mathrm{g} / \mathrm{ml}$

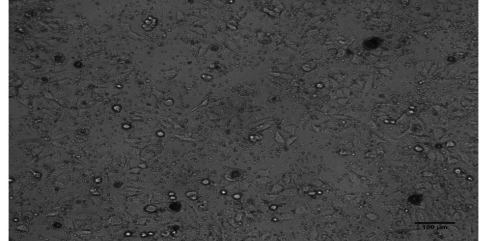

$\mathrm{EF}-1000 \mu \mathrm{g} / \mathrm{ml}$

Plate 2: Images of antitumor activities (\% viability of MCF-7 Cells) of untreated, standard drug Cisplatin $(15 \mu \mathrm{g} / \mathrm{ml})$ and various test concentrations $(200,400,600,800$ and $1,000 \mu \mathrm{g} / \mathrm{ml})$ of E. fetida $(\mathrm{EF})$.

\section{DISCUSSION}

Many researchers found that antitumor activities were found in either CF or extracts of different species of earthworms, such as earthworm coelomic fluid (ECF) which was employed to demonstrate antiproliferation activity on different types of cancers. In addition to this, ECF exhibits other biological activities such as bacteriostatic, proteolytic, cytolytic, and mitogenic activities [16]. The whole earthworm, Pheretima posthuma, tissue has active ingredients involved in fibrolytic activity and considerable cytotoxic and antitumor activities [19]. Earthworm fibrinolytic enzyme (EFE) could also inhibit the proliferation of several cancer cell line in vitro conditions such as gastric cell line - - SCG 7901, esophagus cancer cell line - -Eca-109, cervical cancer cell line - - HeLa, leukemia cell line - - IC562. It suggests that antitumor spectrum of EFE was relatively wide and broad [23,24]. Antitumor activity of serine protease extracted from the Indian earthworm, $P$. posthuma, on MCF-7 cells was also determined by Verma et al. [19]. They observed the inhibition rate of $38.50 \%$ at a concentration of 276.04 and $263.14 \mu \mathrm{g} / \mathrm{ml}$.

The cytotoxic and apoptic activities of the CF of E. fetida were evaluated in vitro by Yanqin et al. [25]. Mohamed Jaabir et al. [26] tested in vitro anticancer activity of CF of the earthworm, 


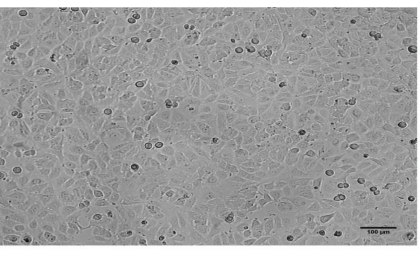

Untreated

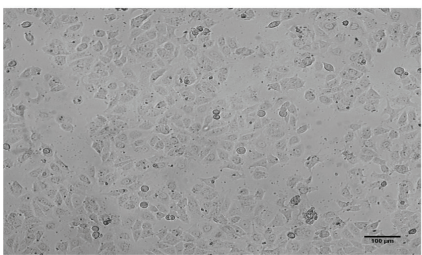

$\mathrm{PE}-200 \mu \mathrm{g} / \mathrm{ml}$

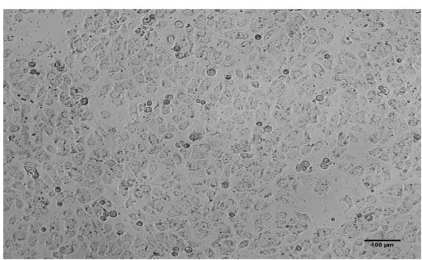

$\mathrm{PE}-600 \mu \mathrm{g} / \mathrm{ml}$

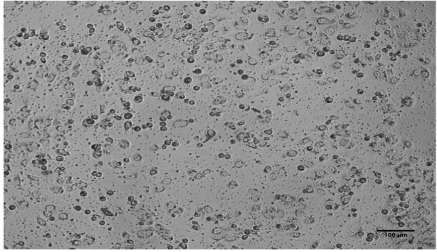

$\mathrm{PE}-1000 \mu \mathrm{g} / \mathrm{m}$

Plate 3: Images of antitumor activities (\% viability of MCF-7 Cells) of untreated, standard drug Cisplatin $(15 \mu \mathrm{g} / \mathrm{ml})$ and various test concentrations $(200,400,600,800$ and $1,000 \mu \mathrm{g} / \mathrm{ml})$ of P. excavatus $(\mathrm{PE})$.

E. eugeniae, on Sitta cells, and they witnessed $68 \%$ of cell death at a higher concentration of $80 \mu \mathrm{g} / \mathrm{ml}$ and $89 \%$ cell death at $100 \mu \mathrm{l} / \mathrm{ml}$ with an $\mathrm{IC}_{50}$ value of $50 \mu \mathrm{l} / \mathrm{ml}$. Dinesh et al. [27] evaluated the in vitro cytotoxic effect of $\mathrm{CF}$ of the earthworm, E. eugeniae on HeLa cells, colon cancer cells, leukemic cells, and brain tumor cells and found dose-dependent inhibitory effect. Therefore, the current study demonstrates that whole E. fetida worm extract has active constituents involved in strong cytotoxic and antitumor activities, but the actual chemical nature and composition of the constituents responsible for these effects are to be explored at molecular levels.

\section{CONCLUSION}

Based on the results obtained in this study, it can be concluded that the antitumor spectrum of the earthworm, E. fetida (113.97 $\mu \mathrm{g} / \mathrm{ml})$, is comparatively more than that of E. eugeniae $(825.67$ $\mu \mathrm{g} / \mathrm{ml})$ and least in $P$. excavatus $(1,617.39 \mu \mathrm{g} / \mathrm{ml})$. The uniqueness of the present study is that here we have covered antiproliferative potentials of three different epigeic earthworm species together and determined successfully. The limitations of this study include the usage of a single cancer cell line (MCF-7 cells) to explore antiproliferative potentials. Therefore, such research on these aspects could be useful for the development of novel therapeutic agents against different types of cancers. Further, experimental studies at molecular levels are required to ascertain the pathways and genes responsible for the anticancer effects, and thereby, we can exploit beneficial aspects of many earthworm species in this respect.

\section{ACKNOWLEDGMENT}

The authors are thankful to the authorities of Karnatak University, Dharwad, for providing necessary facilities to carry out this work at the Department of Zoology, Karnatak University, Dharwad, and UGC, New Delhi, for giving a financial support under SAPDSA-I program to carry out this particular research work. Further, Soumya R. Patil acknowledges with thanks the financial help through URS fellowship by Karnatak University, Dharwad.

\section{CONFLICT OF INTEREST}

Authors declared that they do not have any conflict of interest.

\section{REFERENCES}

1. Lu P, Weaver VM, Werb Z. The extracellular matrix: A dynamic niche in cancer progression. J Cell Biol 2012;196:395-406.

2. Jagtap S, Meganathan K, Wagh V, Winkler J, Hescheler J, Sachinidis A. Chemoprotective mechanism of the natural compounds, epigallocatechin-3-O-gallate, quercetin and curcumin against cancer and cardiovascular diseases. Curr Med Chem 2009;16:1451-62.

3. Arnold M, Sierra MS, Laversanne M, Soerjomataram I, Jemal A, Bray F. Global patterns and trends in colorectal cancer incidence and mortality. Gut 2017;66:683-91.

4. Ferlay J, Soerjomataram I, Ervik M, Forman D, Bray F, Dixit R. Lyon: international agency for research on cancer. Globocan-2012. Cancer Incidence and Mortality Worldwide in 2012, 2012.

5. Siegel RL, Miller KD, Jemal A. Cancer statistics. CA Cancer J Clin 2016;66:7-30.

6. Ferreira D, Adega F, Chaves R. The importance of cancer cell lines as in vitro models in cancer methylome analysis and anticancer drugs testing. Oncogenomics Cancer Proteomics. 2013;6:139-65.

7. Jian Y. Intestinal stem cells injury and protection during cancer therapy. Transl Cancer Res 2013;2(5):384-96.

8. Kim J, Park EJ. Cytotoxic anticancer candidates from natural resources. Curr Med Chem Anticancer Agents 2002;2:485-537.

9. Sabine JR. Earthworms as a source of food and drugs. In: Satchell JE (ed.) Earthworm ecology: from darwin to vermiculture. Chapman and Hall, Cambridge, UK, pp 285-96, 1983.

10. Sun ZJ, Liu XC, Sun LH, Song CY. Earthworm as a potential protein resource. Ecol Food Nutr 1997;36(2-4):221-36.

11. Ayoola PB, Adeyeye A, Onawumi OO. Trace elements and major minerals evaluation of Spondias mombin, Vernonia amygdalina and Momordica charantia leaves. Pak Jour Nutri 2010;9(8):755-8.

12. Chen J. The clinical study on blood coagulation of cancer sufferer. Act Chin Med Pharmacol 1983;2:32.

13. Ismail SA, Pulandiran K, Yegnanarayan R. Anti-inflammatory activity of earthworm extracts. Soil Biol Biochem 1992;24(12):1253-54.

14. Cooper EL, Cossarizza A, Kauschke E, Franceschi C. Cell adhesion and the immune system: a case study using earthworms. Micro Res Tech 1999;4:237-53.

15. Cooper EL, Balamurugan M, Huang CY, Tsao CR, Heredia J, Tommaseo-Ponzetta M. Earthworms dilong: ancient, inexpensive, non controversial models may help clarify approaches to intregated medicine emphasizing neuro-immune systems. Evid Based Compl Alt Med 2012, p. 152-64.

16. Cooper EL, Ru B, Weng N. Earthworms: sources of antimicrobial and anticancer molecules. In Advances in complementary and alternative 
approaches to biomedicine, Kluwer Academic/Plenum, New York, NY, 2004, p. 359-90.

17. Xie JB, He WG, Weng N, Guo ZQ, Yu MM, Liu NN. Extraction and isolation of the anti-tumour protein components from earthworm (Eisenia foetida andrei) and the anti-tumour activity. Chinese J Biochem Mol Biol 2003;19:359-66.

18. Yuan L, Xu JM, Zhou YC. Effects of the purified earthworm extract on various hemal tumour cells. Clin Med J 2004;11:177-9.

19. Verma MK, Xavier F, Verma YK, Sobha K. Evaluations of cytotoxic and antitumor activity of partially purified serine protease isolate from the indian earthworm, Pheretima posthuma. Asian Pac J Trop Biomed 2013;3:896-99.

20. Lourdumary AJ, Ramesh N. Evaluation of anticancer activity of Indian earthworm, Lampito mauritii. Int J Res Pharm Sci 2014;4:27-30.

21. Augustine D, Rao RS, Anbu J, Chidambara Murthy KN. In-vitro antiproliferative effect of earthworm coelomic fluid of Eudrilus eugeniae, Eisenia fetida, and Perionyx excavatus on squamous cell carcinoma-9 cell line: a pilot study. Pharmacognosy Res 2017;9(S1):61-6.

22. Mosmann T. Rapid colorimetric assay for cellular growth and survival: application to proliferation and cytotoxicity assays. J Immunol Methods 1983;65:55-63.

23. Chen H. Anti-tumour effect of earthworm extracts EE2. Chinese Clin Oncol 2001;6:349-50.
24. Chen H, Takahashi S, Imamura M, Okutani E, Zhang Z, Chayama $\mathrm{K}$, Chen B. Enzyme: antitumour activity on human hepatoma cells in vitro and in-vivo. Chinese Med J 2007;120:898-904.

25. Yanqin L, Yan S, Zhenjun S, Shijie L, Chong W, Yan L. Coelomic fluid of the earthworm, Eisenia fetida induces apoptosis of HeLa cells in-vitro. J Eur Soil Biol 2007;43:143-48.

26. Mohamed Jaabir MS, Shamsheerali L, Yasar M, Senthil Kumar S. Evaluation of the cell-free coelomic fluid of the earthworm, Eudrilus eugeniae to induce apoptosis in SiHa cell line. J Pharm Res 2011:4:3417-20.

27. Dinesh MS, Sridhar S, Chandana PG, Pai V, Geetha KS, Naveen HR. Anticancer potentials of peptides of coelomic fluid of earthworm Eudrilus eugeniae. Biosci Biotechnol Res Asia 2013;10:601-6.

\section{How to cite this article:}

Soumya RP, Pulikeshi MB. Evaluation of antitumor activities of different epigeic earthworms. J Appl Biol Biotech 2020;8(04):052-057. DOI: 10.7324/JABB.2020.80408 